\title{
Н.Н. Родигина
}

\section{РЕЦЕНЗИЯ: ЧЕЛОВЕК В МЕНЯЮЩЕМСЯ МИРЕ. ПРОБЛЕМЫ ИДЕНТИЧНОСТИ И СОЦИАЛЬНОЙ АДАПТАЦИИ В ИСТОРИИ И СОВРЕМЕННОСТИ : СБ. НАУЧ. СТ. ТОМСК : ИЗД-ВО ТОМ. УН-ТА, 2015. $296 \mathrm{c.}$}

Проблемы идентичности и социальной адаптации на протяжении последних десятилетий являются предметом напряженного внимания исследователей социального: социологов, социальных антропологов, этнографов, историков и др. Представляется продуктивным стремление организаторов международной научной конференции «Человек в меняющемся мире. Проблемы идентичности и социальной адаптации в истории и современности: методология, методика и практики исследования», проходившей в Томске в октябре 2014 г., одним из результатов которой является рецензируемый сборник, организовать диалог ученых, работающих не только в рамках разных дисциплин, но представляющих различные национальные, тематические, методологические традиции.

Первый тематический раздел сборника объединяет статьи, посвященные анализу процесса формирования территориальных и национальных, гражданских идентичностей (условиям, институтам формирования, символам идентификации и механизмам их трансформации). Н.И. Наумова показывает, как в условиях Гражданской войны изменялись разные виды социальных идентичностей бурят (этнической, надэтнической, региональной, гражданской), какие национальные лидеры и структуры повлияли на эти процессы, как менялась в них роль бурятской интеллигенции и каковы собственно основные характеристики этнической идентификации.

Свой вариант интерпретации городской идентичности жителей современного Норильска предлагает Н.В. Гонина, основываясь на публицистических и мемуарных текстах, фотографиях, материалах устных интервью. Автор выделяет критерии анализа городской идентичности, раскрывает разноплановые условия, оказавшие влияние на ее содержание, приводит словамаркеры, описывающие отношение горожан к своему городу. На мой взгляд, исследование было бы более завершенным в случае сопоставления репрезентаций городской идентичности в разных видах текстов (публицистика, визуальные источники, интервью, воспоминания и пр.) и выявления ее исторической (а возможно, и поколенческой) динамики.

Мне показался спорным замысел любопытной и по сути постановочной статьи М.А. Воскресенской об идентичности творцов Серебряного века. О какой особой идентичности идет речь? Людей, осознававших, что они «творят Серебряный век»? Автор в качестве критерия использует противопоставление «культурной элиты» и «общей разночинской массы». Какая «общая разночинская масса» имеется в виду, учитывая достаточно большое количество описанных в историографии идеологических, социокультурных, поколенческих, профессиональных сообществ русской интеллигенции второй половины XIX - начала XX в. и соответствующих им идентичностей? Насколько те, кого автор называет «культурной элитой» (в данном случае не хватает определения этого понятия), осознавали свое групповое единство, имея в виду многочисленные кружки, общества, творческие группы, о которых упоминает и сама исследовательница? Как соотносятся между собой используемые в статье категории «культурная элита» и «творцы Серебряного века»? Исключительно как синонимы?

Интерес для специалистов по национальной идентичности и широкого круга читателей, неравнодушных к этносоциальным проблемам современности, представляют статьи Д.А. Аманжоловой, Л.В. Дериглазовой, Г.С. Климовой, А. Верцинской. Исследователи на примере конкретных этнических, гражданских, цивилизационных общностей актуализируют сюжеты о критериях и уровнях национальной идентичности, их иерархии, методологических подходах к их изучению, факторах, влияющих на их конструирование в исторической динамике, формы репрезентации этнического.

В историографической статье В.В. Агеевой раскрыты основные направления, тематические и методологические приоритеты изучения постсоветской национальной идентичности англо-американскими специалистами в области Russian Studies двух последних десятилетий, убедительно аргументирована авторская версия причин «застревания» современного россиеведения на проблемах «постидентичности», кризиса «постсоциалистического» состояния национального самосознания; выявлены мнения зарубежных исследователей об условиях, предопределивших особенности национальной идентичности современных россиян; показана связь исследований гендера, гражданственности и империализма.

Во втором тематическом разделе собраны публикации о сибирской региональной идентичности в ее исторической ретроспективе. Продуктивной и неожиданной представляется идея Н.Г. Суворовой - выяснить, как 
преломлялись конкурирующие проекты конструирования «русскости» и «сибирскости» в практике управления крестьянами на уровне волостных правлений и судов, охарактеризовать собственно крестьянские представления о территориальной идентификации. Автор выделяет этапы, механизмы и факторы формирования идентичности крестьянского населения региона, выявляет номинации сельского населения в документах официального делопроизводства, определяет реакцию крестьянского сообщества на процессы конструирования «полезных» идентичностей «сверху» различными акторами процесса научной и административной колонизации Сибири. Выводы статьи провоцируют на вопросы о том, насколько властью (на разных уровнях), областниками, политическими ссыльными и другими претендентами на роль демиургов территориальной идентичности сибирских крестьян учитывалось мнение сельских жителей по этому поводу, как именно данное мнение репрезентировалось в других видах источников. К примеру, в письмах (не только «во власть», но и в периодические издания, родственникам и т.д.), в этнографических описаниях современников и пр.

Статья В.В. Шевцова о репрезентации Сибири и сибиряков на страницах губернских ведомостей расширяет существующие в историографии областничества и истории региональной журналистики представления о роли неофициальных отделов ведомостей в конце $1850-\mathrm{x}$ - начале $1860-\mathrm{x}$ гг. в формировании региональной повестки дня, в актуализации «сибирских вопросов». Исследование побуждает задуматься, насколько перечень злободневных проблем Сибири и путей их решения совпадал с областнической программой и что в нем было типичного для «пробуждающегося» территориального самосознания других провинций / окраин Российской империи. Иначе говоря, насколько собственно самобытно-сибирским, судя по региональной официальной периодике, было областничество, или справедливо утверждение литературоведа Г.А. Бялого, понимавшего под областничеством интерес к провинции, культурническую деятельность народнической интеллигенции по ее изучению и просвещению, своеобразную замену «хождения в народ» [1. С. 95].

Практической реализации либеральных проектов мобилизации населения Сибири по территориальному принципу в годы Первой мировой войны посвящена работа О.А. Харусь. Историк акцентирует внимание на факторах и, что особенно важно, мотивах процесса актуализации региональной идентичности в условиях общероссийского патриотического подъема 1914 1916 гг.; приводит примеры попыток институализации регионального самосознания; рассматривает причины неэффективности деятельности местной либеральной интеллигенции по консолидации населения по терри- ториальному признаку. Представляется удачным исследовательский фокус статьи, дающий возможность понять, как именно события, актуализирующие национальную и гражданскую идентичность, влияют на конструирование регионального самосознания. Однако это акцентирует и вопрос о преемственности и разрывах в деятельности либералов в данном направлении в сравнении с предшествующим мирным периодом начала $\mathrm{XX}$ столетия.

Авторы многочисленных исследований этнической идентичности современных сибиряков М.А. Жигунова, А.А. Анисимова, О.Г. Ечевская на разноплановых источниках и при помощи разных исследовательских стратегий описывают варианты репрезентации своей «сибирскости» нашими современниками и земляками, выявляют место региональной идентичности в иерархии других «принадлежностей», определяют маркеры, фиксирующие специфику сибирского регионального самосознания.

В третьем разделе обсуждаются сюжеты, связанные с адаптацией «принимающего общества» и мигрантов. В методологической статье В.И. Дятлова поставлены вопросы о правомерности употребления для современной России понятия «принимающего общества», использовании подходов безопасности и развития в понимании трансграничной миграции в научном, массмедиа, властном и других дискурсах, о причинах и формах мигрантофобии в контексте современного нациестроительства. Л.А. Кутилова, Г.Н. Алишина, А.Н. Алексеенко, Е.П. Зимовина, Н.П. Погодаев, Е.А. Омельченко на конкретно-исторических примерах рассматривают связь миграции с процессами формирования и трансформации национальной идентичности.

Самый скромный по объему тематический блок посвящен разным вариантам корпоративной идентичности: университетскому преподавательскому сообществу (М.В. Грибовский), региональной корпорации сибирских историков 1930-1940-х гг., этическому кодексу университета как инструменту самоидентификации (Т.В. Трубникова, Н.С. Гулиус).

Замысел сборника, подобно пазлу, объединил статьи о разных видах идентичности (национальной, конфессиональной, территориальной, профессиональной), потенциале разных методологических, тематических подходов и источников исследований идентичности и адаптации. К сожалению, вне поля зрения авторов остались сословная, поколенческая, гендерная идентичности, что дает основания надеяться на новые конференции и публикации по названной проблематике. Сборник представляет несомненный интерес не только для академических исследователей, но и для студентов гуманитарных специальностей, всех, кто интересуется проблемами идентичности и социальной адаптации. 
ЛИТЕРАТУРА

1. Бялый Г.А. В.Г. Короленко. Л., 1983.

Rodigina Nataliya N. Tobolsk complex scientific station of the Ural Branch of RAS (Tobolsk, Russia); Novosibirsk State Pedagogical University (Novosibirsk, Russia). E-mail: natrodigina@list.ru

REVIEW : MAN IN A CHANGING WORLD. IDENTITY AND SOCIAL ADAPTATION IN HISTORY AND MODERNITY: METHODOLOGY, METHODS AND PRACTICES OF RESEARCH: COLLECTION OF SCIENTIFIC ARTICLES. TOMSK : TOMSK UNIVERSITY PRESS, 2015. 296 p.

\section{REFERENCES}

1. Byalyy, G.A. (1983) V.G. Korolenko. Leningrad: Khudozhestvennaya literatura. 